TITLE:

\title{
Multiple symmetric periodic solutions to the 2n-body problem with equal masses(Abstract_要旨)
}

\section{$\operatorname{AUTHOR(S):~}$}

Shibayama, Mitsuru

\section{CITATION:}

Shibayama, Mitsuru. Multiple symmetric periodic solutions to the $2 n$-body problem with equal masses. 京都大学, 2007, 博士(理学)

ISSUE DATE:

2007-03-23

URL:

http://hdl.handle.net/2433/136738

RIGHT: 


\begin{tabular}{|c|c|}
\hline 名 & 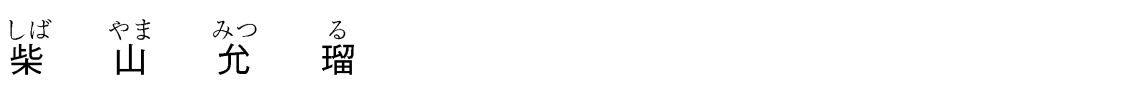 \\
\hline 学位(専攻分野) & 士 (理 学) \\
\hline 学 位 記 番 号 & 理 博 第 3100 号 \\
\hline 学位授与の日付 & 平成 19 年 3 月 23 日 \\
\hline 学位授与の要件 & 学位規則第 4 条第 1 項該当 \\
\hline 研究科・専攻 & 理学研究科数学 - 数理解析専攻 \\
\hline 学位論文題目 & $\begin{array}{l}\text { Multiple Symmetric Periodic Solutions to the } 2 n \text {-body Problem with } \\
\text { Equal Masses } \\
\text { (等質量の } 2 n \text { 体問題の多様な対称性を持つ周期解) }\end{array}$ \\
\hline
\end{tabular}

\section{論文内容の要旨}

重力の相互作用の下での 3 個の質点の運動を調べる 3 体問題を初めとする天体力学は Newton, Euler, Lagrange らの先駆 者の業績に始まる長い歴史を持ち, 20 世紀初頭の Poincaré, 50-60 年代の Kolmogorov, Arnold, Moser らの研究などに見 られるように解析学, 幾何学を含む数学の多くの分野と密接に関わり, 多大な影響を相互に及ぼしあいながら発展してきた。 2000年には Chenciner と Montgomery がEuler, Lagrange 以来とも言われる平面 3 体問題の新しい周期解を発見し, 変分 法を用いた多体問題の研究に新しい展開をもたらした。本申請論文もこの研究の流れにあって, 偶数体問題における新しい 周期解の系列の存在を示したものである。

$N$ 個の質点の重力の相互作用による運動を調べる $N$ 体問題

$$
m_{i} \frac{d^{2} x_{i}}{d t^{2}}=-\sum_{j \neq i} \frac{m_{i} m_{j}\left(x_{i}-x_{j}\right)}{\left|x_{i}-x_{j}\right|^{3}} \quad x_{1}, \cdots, x_{N} \in \mathrm{R}^{d}
$$

を考える。ここで, $m \geq 0$ は質点の質量， $x_{i}$ は質点の位置である。

本論文で申請者が研究したのは等質量の平面 $2 n$ 体問題で配置が常に $2 つ の$ 正 $n$ 角形を成すという対称性を保つ周期解の 存在問題である。各 $n$ に対してその対称性をもつ周期解は少なくとも 1 つ存在することはすでに証明されていたが，申請 者は $2 n$ 体問題のそのような対称性をもつ周期解は実はもっと多く存在することを証明した. その結果を正確に述べると次 のようになる。

定理 各 $n \geq 2$ と任意の $T>0$ と各 $p=1, \cdots,[n / 2]$ ([ ] はガウス記号) に対して, 次の性質をもつ等質量の平面 $2 n$ 体 問題の $T$-周期解 $x_{1}, \cdots, x_{2 n}$ が存在する : 滑らかな閉曲線 $\alpha_{1}:[0, T] \rightarrow \mathrm{R}^{2}$ が存在して, それと合同な閉曲線 $\alpha_{2}, \cdots, \alpha_{2 d}$ を，

$$
\alpha_{2}(t)=\exp \left(\frac{\pi \sqrt{-1}}{n}\right) \alpha_{1}(-t), \quad \alpha_{2 j+1}=\omega^{j} \alpha_{1}, \quad \alpha_{2 j}=\omega^{j} \alpha_{2}
$$

と定義する。ただし $d$ はと $n$ との最大公約数で, $\omega=\exp (2 \pi \sqrt{-1} / n), j=1, \cdots, d-1$ とする。このとき周期解 $x_{1}, \cdots$, $x_{2 n}$ はつぎのように表すことができる：

$$
x_{2 j+2 k p-1}(t)=\alpha_{2 j-1}(t+2 k \bar{T}), \quad x_{2 j+2 k p}(t)=\alpha_{2 j}(t-2 k \bar{T}) .
$$

ここで, $\ell=n / d, \quad \bar{T}=T / 2 \ell, \quad 1 \leq j \leq d, 0 \leq k \leq \ell-1$ であり, 指数は $2 n$ を法として考える。さらに, $\alpha_{1}$ は $2 \pi / \ell$ 回転で不変 で， $\alpha$ の角運動量は常に非負（すなわち $\alpha_{1} \wedge \dot{\alpha}_{1} \geq 0$ ) であり， 1 周期の間に原点の回りを $p / d$ 周まわる。

この定理において, $n$ が奇数で $p=1$ の場合と $n$ が偶数で $p=n / 2$ の場合は K. - C. Chen や Ferrario-Terraciniによってす でに知られていたが，その他の $p$ に関しては新しい周期解であり，従ってこの定理によって各 $n$ に対して $[n / 2]-1$ 個の新 たな周期解が得られた。また，一般に変分法を用いて得られた解はその性質があまりよく分からないことが多いが，ここで 
は角運動量の符号の評価も得られており，これはすでに知られていた周期解に対しても新しい結果である。

\section{論 文 審査の 結 果 の 要 旨}

天体力学の問題の数学的研究では, 近年, 変分法を用いた多体問題の周期解の存在に関する研究において大きな進展があ つた。このような発展の先駆けとなったのは Chenciner と Montgomery による 3 体問題の 8 の字解の存在証明である。彼 らは等質量の平面 3 体問題において変分法と対称性を用いて，3 質点が 8 の字形の閉曲線の上を互いに追跡しあうような運 動をする新しい周期解の存在を証明し, Euler や Lagrange 以来の 3 体問題の新しい周期解の発見として大きな注目を集め た。その後, Chen やFerrario, Terracini らはその手法を発展させ多くの周期解の存在を証明した。またSimóによる数値 計算結果では，極めて多様な形状を持つ多くの周期解の存在が強く示唆されている。

申請者柴山允瑠による学位申請論文は, $2 n$ 個の質点が正 $n$ 角形配置を保ちながら運動するような対称性を持つ新しい周 期解の族の存在を変分法を用いて証明したものである。このような形状を持つ周期解の存在は既に部分的には知られていた が，申請者はそれらとは独立に，独自の方法でこのような周期解の存在を示したものである。特に，Chenらの方法では区 別できない周期解の形状の違いを区別し，同一の対称性を持ちながら形状が異なる周期解の存在を示したことは特筆に值す る。この方法は，今後，同様の問題を扱う際に有力な方法の一つとして用いられると期待される。申請者はまた，これらの 周期解の角運動量についても若干の情報が得られることも示した。通常，変分法を用いた解の存在証明では，得られた解の 持つ性質を知ることが困難な場合が多いが，申請者の方法は解の構成方法をうまく利用することにより，周期解の角運動量 が非負であることが示せており，その点でも興味深い結果である。

本論文で存在が証明された多体問題の高い対称性を持つ周期解は，それ自体が何らかの現実性のある解と直ちに考えられ るわけではないが，例えば人工衛星の軌道の制御などの場面で利用できる可能性もある。またこのような解の存在を扱う数 学的手法は宇宙工学などでも応用可能な方法であると思われるので, 今後, そのような方向での研究の発展も期待される。

参考論文は, 平面または空間 3 体問題において 3 体衝突がおきる状況を詳しく解析することにより, 近 3 体衝突を伴う振 動解と呼ばれる特徵的な振る舞いをする解の存在を示した申請者の最新の結果であり，申請者の研究の新しい方向を示す興 味深いものである。

以上により，本申請論文は博士 (理学) の学位論文として価值あるものと認めた。また，主論文の内容を中心に，それに 関連した事項について試問した結果，合格と認めた。 